\title{
Informal credit constraints and farmers' health: an empirical study of China
}

\author{
Xinyue Dong ${ }^{1}$ (D) Fan Yang $^{2 *}$ (i) \\ ${ }^{1}$ College of Management, Chongqing University of Technology, Chongqing, China. \\ ${ }^{2}$ School of Public Administration, Sichuan University, 610065, Chengdu, Sichuan, China. E-mail: yangfan1987@scu.edu.cn. . ${ }^{*}$ Corresponding author.
}

\begin{abstract}
Based on survey data of the income distribution and living conditions of urban and rural residents collected by the China Economic Monitoring and Analysis Center in 2014, we investigated the mechanisms related to informal credit constraints on farmer health and then empirically analyzed the impacts of such constraints. Results showed that, in general, informal credit constraints significantly negatively impact farmer health. Compared with farmers whose credit was not informally constrained, the probability of farmers who faced informal credit constraints describing their self-rated health as "very good" fell by 6.64\%. After controlling for endogenous problems, this proportion rose to $28.87 \%$. Correspondingly, the probability of describing self-rated health as "very bad" increased by $0.45 \%$. After controlling for endogenous problems, this proportion rose to $0.81 \%$. The robustness test showed that our conclusions are strongly robust. Informal credit constraints significantly positively impacted the number of days of illness in 2013 in the sample of farmers, which means farmers who suffered from informal credit constraints required more sick days than those who did not experience informal credit constraints in 2013. As far as we know, this is the first study on the impact of informal credit constraints on Chinese farmer health.

Key words: informal credit constraints, farmer, health, individual welfare, sustainable development.
\end{abstract}

Restrições ao crédito e à saúde de agricultores: um estudo empírico da China

RESUMO: Com base nos dados da pesquisa sobre a distribuição de renda e as condições de vida dos residentes urbanos e rurais coletados pelo Centro de Análise e Monitoramento Econômico da China em 2014, investigamos os mecanismos relacionados às restrições informais de crédito à saúde dos agricultores e, em seguida, analisamos empiricamente os impactos dessas restrições. Os resultados mostram que, em geral, as restrições informais de crédito afetam significativamente a saúde dos agricultores. Em comparação com os agricultores cujo crédito não foi informalmente restrito, a probabilidade de agricultores que enfrentaram restrições informais de crédito que descrevem sua auto-avaliação de saúde como "muito boa" caiu 6,64\%. Após o controle de problemas endógenos, essa proporção subiu para 28,87\%. Da mesma forma, a probabilidade de descrever a auto-avaliação de saúde como "muito ruim" aumentou 0,45\%. Após o controle de problemas endógenos, essa proporção subiu para $0,81 \%$. O teste de robustez mostrou que nossas conclusões são fortemente robustas. As restrições informais de crédito impactaram significativamente o número de dias de doença em 2013 na amostra de agricultores, o que significa que os agricultores que sofreram restrições informais de crédito permaneceram mais dias doentes do que aqueles que não tiveram restrições informais de crédito em 2013. Tanto quanto sabemos, este é o primeiro estudo sobre o impacto das restrições informais ao crédito na saúde dos agricultores chineses. Palavras-chave: restrições informais de crédito, agricultor, saúde, bem-estar individual, desenvolvimento sustentável.

\section{INTRODUCTION}

Health is one of the ultimate goals of human development (SEN, 1999). With the development of the social economy, health has become a focus. The Chinese government attaches importance to people's health. In August 2016, the National Health Conference was held in Beijing and the meeting emphasized that people's health should be given development priority (CGN, 2016). In October 2017, the Report of the 19th National Congress of the Communist Party of China proposed the implementation of the Healthy China strategy (PDO, 2017). In March 2018, the State Council's Institutional Reform Program proposed the establishment of the National Health Commission and the National
Healthcare Security Administration (SOHU, 2018). The above series of major initiatives showed that the theme of Healthy China has become a national strategy and people's health is now highly valued.

The importance of health has two meanings. First, for individuals, health is the basic prerequisite for sustainable development. Health is the most basic type of individual human capital, the carrier of other types of human capital, and the basis for an individual to survive and realize their development (SCHULTZ, 1961). Second, for society, individual health is an important basis for sustainable social development. Health directly determines the role of human function and individuals' ability to work, thus affecting the labor market, social production efficiency, and 
social and economic conditions. Previous studies have shown that a significant positive correlation exists between health and socioeconomic status (CLAUSSEN, 2015; MARMOT et al., 1997).

Farmers' health is one of the elements of human capital in rural areas. The health status of farmers directly affects the quantity and quality of rural labor. Farmers' health status not only affects the efficiency of agricultural production (FINK \& MASIYE, 2015; SIMON \& SHALLONE, 2013; CROPPENSTEDT \& MULLER, 2000), but also the allocation of human resources of farmers' families, thus affecting farmers' choice of non-agricultural employment (YU, 2015); and subsequently, impacting farmers' livelihood patterns and results. Health status also affects the accumulation of other types of human capital of farmers (BLEAKLEY, 2010). For example, those in poor health have less access to education, which affects the improvement of their human capital stock (OGUNDARI \& AWOKUSE, 2018). Using data from the 2006 China Health Survey and the 2009 Nutrition Survey, Liu adopted the probit regression model and reported that the better the health status of farmers, the higher the possibility of labor participation and the lower the probability of poverty (LIU, 2008). Therefore, health has a crucial impact on individual farmers, poor households, and rural economic development.

Health is affected by many factors, including individual factors such as gender, age, education, income, marital status, eating habits (PARK et al., 2002; KESSLER \& CLEARY, 1980; ETTNER, 1996); family factors such as living environment and family scale (ETTNER, 1996; PENNINGTON et al., 2018), and social factors such as social medical services and social support networks (ETTNER, 1996; MILLER et al., 2006; COLEMAN, 1988). In previous studies, some scholars have noticed that informal credit constraints (including loans between relatives and friends or loans from informal financial organizations) as a form of social support have a certain impact on individual health. For example, ZHOU et al. (2014) reported that private lending and transfer payment between relatives and friends, as one of the forms of social capital, can play a positive role in the acquisition of medical resources and health care behavior of farmers, and thus have a positive impact on the health of farmers. KAWACHI (1999) argued that cash loans between neighbors have a positive impact on the health of individuals living in poor communities. COHEN et al. (2000) believed that borrowing as an instrumental social support can provide members of the social network with help to prevent diseases, thereby having a positive impact on the health of members in the community. However, as far as we know, most of the studies on the impact of informal credit constraints on health only appear in the form of social capital elements (CULLEN et al., 2001). To date, there has not been a separate study on the impact of informal credit constraints on the health of farmers. Therefore, this paper conducts an empirical study on the relationship between informal credit constraints and the health of farmers in rural China.

Therefore, the main objectives and contributions of this paper are as follows: First, our findings enrich the literature on the factors influencing farmers' health; second, we theoretically explain the mechanism of informal credit constraints on farmers' health, and then we empirically analyzed this impact. Third, this paper proposes a path to prevent the impact of informal credit constraints on farmers' health from two perspectives: improving the informal credit system and improving the rural formal financial market.

The remainder of this paper are organized as follows: In Section 2, we explained the mechanism by which informal credit constraints affect farmers' health; in Section 3, we described the data sources used in this paper, define variables, and set up mathematical models; in Section 4, we provided the results of the study; and in Section 5, we outlined our conclusions and suggested some policy implications, including some shortcomings of this study upon which researchers can reference, expand, and deepen.

\section{Theoretical framework}

As the core of the modern rural economy, finance is an important driving force for rural social economic development and farmers' income growth. China is experiencing a period of poverty alleviation and rural revitalization. Rural financial support is urgently required, whether the improvement of farmers' income levels or the development of the rural social economy. Specifically, the suppliers of rural financial support mainly include formal financial institutions, informal financial organizations, and individuals. Many studies have shown that farmers' credit behavior mainly involves borrowing from informal financial institutions due to the difficulty of obtaining loans through formal financial institutions, the high cost of financing from formal financial institutions, and farmers' lack of awareness of formal financial loans (TURVEY et al., 2010; KOCHAR, 1997; PETRICK, 2004; SIAMWALLA et al., 1990; JIA et al., 2010; HOFF \& STIGLITZ, 1990). A survey of farmers' loan behaviors in Mekong Delta in 
Vietnam showed that the proportion of farmers' loans from informal financial channels is much higher than that from formal financial channels (KHOI et al., 2013). Thus, informal credit plays an important role in the rural financial system. However, as the main channel of farmers' loans, informal credit is also facing serious constraints. This means that farmers cannot obtain loans from informal financial organizations or individuals (such as relatives and friends) to meet their loan needs. The study showed that the reasons why farmers are constrained by informal credit are information asymmetry, a lack of collateral, and reputation (AYYAGARI et al., 2010).

Informal credit constraints have many negative impacts on farmers, such as reducing household income and consumption expenditure and lowering household welfare (KUMAR et al., 2013; TRAN et al., 2016). Decreases in income and consumption and an increase in economic vulnerability will impact farmer health. Accordingly, we hypothesize that informal credit constraints significantly and negatively affect farmer health.

First, informal credit constraints affect farmers' incomes, subsequently affecting their health. This occurs through two main pathways. (1) As informal credit constraints lower the direct productive investment, farmers' productive income is reduced. (2) Informal credit constraints increase the occupancy of funds through preventive saving behavior by farmers and also reduce the amount of money that farmers can use for productive investment, thus reducing farmers' productive income (YUSUF et al., 2015). A study focused on 1800 farmers in the Jiangsu and Shandong provinces in China showed that informal credit constraints reduce farmers' productive and operational incomes by $13.5 \%$ (LI \& SUN, 2018). Generally, the decrease of income means less access to education and material resources. Lacking human capital and material capital is not conducive to the improvement of health. Therefore, lower income may have a negative influence on farmers' health (WAGSTAFF \& DOORSLAER, 2000; COLEMAN, 2000; MILLER et al., 2006; ZHOU et al., 2014). Therefore, informal credit constraints influence the health status of farmers by affecting their income.

Second, informal credit constraints affect farmers' consumption, thereby affecting their health. Informal credit constraints directly and indirectly affect farmers' consumption expenditure through the following mechanisms. (1) Informal credit constraints affect the amount of money held by farmers, directly affecting their monetary expenditure for consumption (BACCHETTA \& GERLACH,
1997). (2) Risk-averse farmers preventatively save to reduce the risk due to the uncertainty of future income. Farmers facing informal credit constraints realize that they cannot obtain funds to manage the risks associated with informal credit when accidents occur in the future, so they increase their household preventive savings, reducing their current monetary expenditure for consumption (QIU \& HU, 2018). A study of 1800 households in Jiangsu and Shandong provinces showed that informal credit constraints reduced household spending by $14.7 \%$ (LI \& SUN, 2018). Another study including 1730 households in Shandong, Henan, and Guangxi provinces showed that informal credit funds are mainly used for consumption expenditure, of which $36.33 \%$ are used for medical treatment and for children to attend school (HE et al., 2018). Faced with informal credit constraints, farmers' consumption capacity declines, as the money they have is insufficient to buy food to maintain their health, and they cannot pay medical expenses when they are sick, which reduces their ability to resist health risks and may even worsen health conditions. Therefore, informal credit constraints affect farmers' health by affecting their consumption.

Third, informal credit constraints affect farmers' economic vulnerability, thereby affecting their health. Studies showed that informal credit can prevent and reduce the risk of farmers' economic vulnerability (HE et al., 2013). Therefore, informal credit constraints increase the economic vulnerability of farmers, thus affecting their health. Farmers' economic vulnerability affects their health mainly through economic and psychological aspects. From the economic perspective, an increase in farmers' economic vulnerability increases their labor input time to lower their economic vulnerability, resulting in overloading of their physical functions and increased negative impacts on their health (PORTERFIELD, 2001). From the psychological perspective, an increase in farmers' economic vulnerability will aggravate their psychological burden (ALDWIN \& REVENSON, 1986), leading to increases in the prevalence of mental and physical diseases, which negatively impact health. Therefore, informal credit constraints affect farmers' health by affecting their economic vulnerability.

In summary, three main aspects of informal credit constraints affect farmer health: first, by affecting farmers' income; second, by affecting farmers' consumption expenditure; and third, by affecting farmers' economic vulnerability. In the third part of this paper, we described an empirical test conducted on the impact of informal credit constraints on farmers' health. 
Data, variables, and models

Data sources

The data used in this paper were obtained from a survey on the income distribution and living conditions of urban and rural residents organized by the China Economic Monitoring and Analysis Center of the National Bureau of Statistics conducted in 2014. The data covered 160,000 households living in all 31 provinces (municipalities, autonomous regions) of mainland China. Samples were obtained by a systematic sampling method. In total, there were 18,948 household samples and 64,777 individual samples selected from 234 counties (districts) from 126 cities in 15 provinces, including 7175 urban household samples, 11,013 rural household samples, and 760 migrant workers samples. We used the rural household samples. As per the research needs, data from 25,268 individuals aged between 18 and 65 years were selected for empirical study.

\section{Variables selection \\ Dependent variable}

The dependent variable used in this study was farmers' health. Many methods are available to evaluate individual health. The health data used in this study were self-rated, i.e., the health status of samples was rated by the individuals themselves (IDLER \& BENYAMINI, 1997). This is the most direct method of individual health assessment because the individual has the most direct perception of their health status. This method has been used in many studies (KENNEDY et al., 1998; MA et al., 2017; CAI et al., 2017; SELVAMANI et al., 2018; WILSON et al., 2019). A study reported that self-rated health is more predictive of individual mortality than personal medical records (ERIC, 1970). Simultaneously, it is easier to measure individual health through selfrated health. Therefore, the use of self-rated health as an evaluation method has a certain level scientific operability. In this study, five levels of self-rated health were used: health was rated on a scale of 1 to 5 , denoting very bad, bad, general, good, and very good health, respectively.

\section{Independent variable}

The independent variable used in this study was informal credit constraint. Compared with formal credit, informal credit refers to credit loans obtained from civil organizations and friends and relatives (CHAUDHURI \& GUPTA, 1996). We determined whether farmers had encountered informal credit constraints after knowing whether they needed or received informal credit. In cases where farmers needed informal credit but failed to obtain it or received an insufficient amount, we judged that the farmer had encountered informal credit constraints; otherwise, they were deemed not to have encountered informal credit constraints. Therefore, the independent variable used in this study was a 0 or 1 variable.

\section{Control variables}

In addition to the informal credit constraints, many other factors influence individual health (AKDEMIR et al., 2019). Therefore, we also selected some control variables. These control variables can be summarized into three categories: individual characteristics of farmers, such as gender, age, and education; family characteristics, such as family size and household income per capita; and geographical characteristics, namely province. Each variable is defined in table 1.

\section{Model settings}

Considering health is a type of limited ordered data, estimations from ordinary least squares (OLS) would be biased and inconsistent. Therefore, we used the ordered probit (Oprobit) model for regression. The Oprobit model is a typical limited dependent variable model. Its core idea is to establish an Oprobit model for observable ordered data to study the change in the unobservable latent variable

(DAYKIN \& MOFFATT, 2002). As the value of $y_{i}^{*}$ cannot be observed, the health $y_{i}^{*}$ of farmers can be regarded as a latent variable. The linear equation of

$y_{i}^{*}$ can be expressed as:

$y_{i}^{*}=\beta I C C_{i}+\eta x_{i}+\varepsilon_{i}, i=1,2, \ldots, N$

where $y_{i}^{*}$ is farmers' potential health; $I C C_{i}$ is the informal credit constraint, which is the independent variable that we are most concerned with; $\beta$ is the coefficient of the informal credit constraint $I C C_{i}$; $x_{i}$ is a series of control variables affecting farmers' health; $\eta$ is the coefficient of control variables; and $\varepsilon_{i}$ is the residual term. Although $y_{i}^{*}$ is an unobservable latent variable, it has the following relationship with another observable ordered series, $y_{i}$ :

$$
y_{i}=F\left(y_{i}^{*}\right)=\left\{\begin{array}{c}
1 y_{i}^{*}<\alpha_{1} \\
2 \alpha_{1} \leq y_{i}^{*}<\alpha_{2} \\
\cdots \\
J \alpha_{J-1} \leq y_{i}^{*}
\end{array}\right.
$$


Table 1 - Definitions of the main variables and descriptive statistical results $(N=25,268)$.

\begin{tabular}{|c|c|c|c|c|c|}
\hline Variable & Definition & Average & SD & Min & Max \\
\hline Self-rated health & $\begin{array}{c}1=\text { very bad; } 2=\text { bad; } 3= \\
\text { general; } 4=\text { good; } 5=\text { very } \\
\text { good }\end{array}$ & 4.024 & 0.857 & 1 & 5 \\
\hline $\begin{array}{l}\text { Informal credit } \\
\text { constraints }\end{array}$ & $\begin{array}{c}1=\text { facing constraints; } 0=\text { not } \\
\text { facing constraints }\end{array}$ & 0.178 & 0.383 & 0 & 1 \\
\hline Gender & $\begin{array}{c}1=\text { male } \\
0=\text { female }\end{array}$ & 0.522 & 0.500 & 0 & 1 \\
\hline Age & Age (years) & 41.112 & 13.462 & 18 & 65 \\
\hline Family ranking & $\begin{array}{c}1=\text { ranking first among } \\
\text { brothers and sisters; } \\
0=\text { other }\end{array}$ & 0.3911 & 0.488 & 0 & 1 \\
\hline Nation & $1=$ Han nationality $; 0=$ other & 0.924 & 0.264 & 0 & 1 \\
\hline Party member & $\begin{array}{l}1=\text { member of the Chinese } \\
\text { Communist Party; } 0=\text { other }\end{array}$ & 0.055 & 0.228 & 0 & 1 \\
\hline Cadre & $1=$ cadre $; 0=$ other & 0.026 & 0.158 & 0 & 1 \\
\hline Education & No. years schooling & 8.155 & 3.210 & 0 & 21 \\
\hline $\begin{array}{l}\text { Endowment } \\
\text { insurance }\end{array}$ & $\begin{array}{c}1=\text { purchased pension } \\
\text { insurance; } 0=\text { no purchase }\end{array}$ & 0.777 & 0.416 & 0 & 1 \\
\hline $\begin{array}{l}\text { Family life } \\
\text { vulnerability }\end{array}$ & $\begin{array}{c}1=\text { weak } ; 2=\text { general; } 3= \\
\text { strong }\end{array}$ & 2.039 & 0.485 & 1 & 3 \\
\hline Family size & No. in household & 4.302 & 1.432 & 1 & 13 \\
\hline $\begin{array}{l}\text { Per capita household } \\
\text { debt }\end{array}$ & $\begin{array}{l}\text { Logarithm of per capita } \\
\text { household debt }\end{array}$ & 1.696 & 3.500 & 0 & 12.766 \\
\hline $\begin{array}{l}\text { Per capita household } \\
\text { income }\end{array}$ & $\begin{array}{l}\text { Logarithm of per capita } \\
\text { household income }\end{array}$ & 9.210 & 0.729 & 4.759 & 13.187 \\
\hline $\begin{array}{l}\text { Family economic } \\
\text { vulnerability }\end{array}$ & $\begin{array}{l}\text { 1-4 represent the family's } \\
\text { economic vulnerability from } \\
\text { weak to strong }\end{array}$ & 2.826 & 0.643 & 1 & 4 \\
\hline
\end{tabular}

where $y_{i}$ is a discrete array $\{1,2, \ldots, J\}$, which represents the self-rated health of the $i$ th peasant. $\alpha_{1}<\alpha_{2}<\cdots<\alpha_{J}$ is the cut-point parameter to be estimated; and $y_{i}^{*}$ is divided into $J$ intervals, so that the probability that the $i$ th observation $j$ of $y$ falls within a certain interval, which can be expressed as:

$$
P\left(y_{i}=j\right)=\left\{\begin{array}{c}
F\left(\alpha_{1}-\beta I C C_{i}-\eta x_{i}\right) j=1 \\
F\left(\alpha_{j}-\beta I C C_{i}-\eta x_{i}\right)-F\left(\alpha_{j-1}-\beta I C C_{i}-\eta x_{i}\right) 2 \leq j \leq J-1 \\
\ldots \\
1-F\left(\alpha_{j-1}-\beta I C C_{i}-\eta x_{i}\right) j=J
\end{array}\right.
$$

Then, the dependent variable is replaced with $y_{i}$ to build the Oprobit model :
$y_{i}=F\left(\beta I C C_{i}+\eta x_{i}+\varepsilon_{i}\right) i=1,2, \ldots, N$.

According to Equation (4), the logarithm likelihood function corresponding to the $i$ th observation value $j$ can be written as:

$$
\begin{aligned}
& \ln L=\sum_{i=1}^{N} \sum_{j=1}^{J} \ln \left[F\left(\alpha_{j}-\beta I C C_{i}-\eta x_{i}\right)-\right. \\
& \left.F\left(\alpha_{j-1}-\beta I C C_{i}-\eta x_{i}\right)\right]
\end{aligned}
$$

The coefficients $\beta, \eta$, and $\alpha_{i}(j<J)$ of the Oprobit model can be obtained by maximum likelihood estimation. The $\beta$ and $\eta$ obtained using equation (5) are the unbiased and consistent estimates of $\beta$ and $\eta$ in equation (1), respectively. 


\section{RESULTS}

\section{Descriptive statistical analysis}

Detailed definitions and descriptive statistical results of the main variables used in this paper (including interpreted and interpreted variables) are listed in table 1 . Table 1 shows that the self-rated health level of the sample of farmers was high, with an average value of 4.024, which is between good and very good. The average value of informal credit constraints was 0.178 , which means that $17.8 \%$ of farmers experienced informal credit constraints. The average gender value was 0.522 , indicating a male proportion of $52.2 \%$. The average age was 41 , which means that many respondents were in their prime. Combined with the actual situation in rural China, most of the peasants at this age are regarded as the pillar of a family, shouldering the heavy responsibility of earning money and supporting the family. Therefore, their health status is not only related to their living standards, development prospects, and welfare, but also to the survival and sustainable development of a family. The nation average value was 0.924 , which means that Han people accounted for $92.4 \%$ of the survey sample. This is in line with the ethnic distribution of the Chinese population, which confirmed the randomness and scientific nature of the data sampling in this study. The results of the Sixth National Population Census in 2010 showed that Han population accounts for $92 \%$ of the total population in China (NBSC, 2010). The average value of education was 8.155 , which means the sample of farmers had an average of 8.155 years of education. Although, this value is low, it is in line with the actual situation in rural China. Due to space limitations, the descriptive statistics of other major variables are shown in table 1 .

\section{Multicollinearity test of variables}

To ensure the accuracy and stability of the model, we conducted multiple collinearity tests on the data before the regression analysis. The criteria for judging the existence of collinearity are the tolerance and the variance inflation factor (VIF). The smaller the tolerance, the higher the degree interpreted by other variables when an independent variable is used as the dependent variable in the regression analysis, and the more serious the collinearity. The reasonable range of tolerance is $(0.1,+\infty)$. The VIF is the reciprocal of tolerance. If the value is $\geq 10$, severe collinearity may exist between the independent variables (MILES, 2005).

The multicollinearity test, which regarded the informal credit constraint as the dependent variable and other variables as the independent variables, showed a minimum tolerance of $0.316>$ 0.1 and a maximum VIF value of $3.16<10$. Thus, no serious multicollinearity existed. Multicollinearity tests were also performed on other variables; however, due to space limitations, we omitted all the inspection processes. To summarize the inspection results, the tolerance and VIF of the multicollinearity tests were within a reasonable range. Therefore, no serious multicollinearity existed among the variables in the regression equation.

\section{Benchmark regression}

The Oprobit regression results of the effect of informal credit constraints on farmers' self-rated health are reported in table 2 . Only informal constraint variables are added in column 1 of table 2; no other control variables are added. Informal credit constraint variables and province variables are added in column 2. Informal credit constraint variables, individual characteristics, and provincial variables are added in column 3. Informal credit constraint variables, individual characteristics, household characteristics, and provincial variables are added in column 4. As per the coefficient signs and significance of informal credit constraints variables in columns $1-4$, informal credit constraints negatively impacted farmers' health. Therefore, we drew a preliminary conclusion that informal credit constraints significantly and negatively affected farmers' self-rated health.

From the point of view of the marginal effect, compared with farmers who had not encountered informal credit constraints, the probability of farmers who had encountered informal credit constraints choosing to self-rate their health as very bad was $0.45 \%$ higher. Compared with farmers who had experienced informal credit constraints, the probability of farmers choosing to self-rate their health as bad increased by $1.57 \%$. Compared with farmers who had not encountered informal credit constraints, the probability of farmers who had encountered informal credit constraints choosing to self-rate their health as general was $3.51 \%$ higher and choosing to self-rate their health as good was $1.1 \%$ higher. Compared with farmers who had not encountered informal credit constraints, the probability of farmers who faced informal credit constraints choosing to self-rate their health as very good was $6.64 \%$ lower. It indicated from the above results that informal credit constraints can significantly decrease the likelihood of farmers' judging their own health as good and increase the likelihood of judging their own health as bad. This is consistent with our theoretical expectation. The possible reason is that, as we have 
Table 2 - Oprobit regression results of informal credit constraints on farmers' self-rated health $(N=25,268)$.

\begin{tabular}{|c|c|c|c|c|}
\hline Variable & (1) & (2) & (3) & (4) \\
\hline $\begin{array}{l}\text { Informal credit } \\
\text { constraints }\end{array}$ & $\begin{array}{c}-0.2536^{* * *} \\
(0.0352)\end{array}$ & $\begin{array}{c}-0.2353^{* * *} \\
(0.0368)\end{array}$ & $\begin{array}{c}-0.2682^{* * *} \\
(0.0378)\end{array}$ & $\begin{array}{c}-0.2117^{* * *} \\
(0.0390)\end{array}$ \\
\hline Individual characteristics & No & No & Yes & Yes \\
\hline Family characteristics & No & No & No & Yes \\
\hline Province & No & Yes & Yes & Yes \\
\hline
\end{tabular}

Note: ${ }^{* * *},{ }^{* *}$, and ${ }^{*}$ respectively indicate $\mathrm{P}<0.01, \mathrm{P}<0.05$, and $\mathrm{P}<0.1$. The standard errors aggregated at the village level are in parentheses. Marginal effects of information credit constraints on farmers' health: health $=1($ very bad $)=0.0045^{* * *}(0.0009) ;$ health $=2$ $(\mathrm{bad})=0.0157^{* * *}(0.0029)$; health $=3($ general $)=0.0351^{* * *}(0.0065)$; health $=4($ good $)=0.0110^{* *}(0.0031)$; health $=5(\mathrm{very}$ good $)=-$ $0.0664^{* * *}(0.0125)$. To save space, we omitted the regression results of the control variables.

assumed above, informal credit constraints lead to the decrease of farmers' monetary income, the decrease of consumption ability and the increase of economic vulnerability, which have a negative influence on their health.

\section{Average treatment effect regression}

In this study, the outcome of farmers' informal credit constraints was not selected randomly but was rather determined by farmers' self-selected answers. It would have been affected by some unobservable factors that also impact farmers' health. For example, richer farmers have a lower probability of experiencing credit constraints. These farmers have more capital and a higher probability of maintaining good health. Therefore, farmers' informal credit constraints are not the result of random selection, but the result of endogenous selection, and a selection bias problem exists. Thus, in the regression model, we considered the endogenous treatment of farmers' informal credit constraints using the Oprobit model with endogenous treatment to estimate the regression. Since the binary variable of informal credit constraints of farmers is defined as processing assignment variables, it interacts with all other control variables in the regression equation of farmers' health. Due to limited space, we do not show the regression results of the extended probit model.

The regression results of the average treatment effect of informal credit constraints on farmers' self-rated health are reported in table 3. Table 3 shows that, compared with farmers who had not encountered informal credit constraints, the probability of farmers who had encountered informal credit constraints choosing to self-rate their health as very bad was $0.81 \%$ higher. Compared with farmers who had not encountered informal credit constraints, the probability of farmers who had faced informal credit constraints choosing to self-rate their health as bad was $3.95 \%$ higher. Through the above two regression results, it can be reported that farmers who encounter informal credit constraints are more likely to fall into health risk perception.

Compared with farmers who had not encountered informal credit constraints, the probability of farmers who had faced informal credit constraints choosing to self-rate their health as very good was $28.87 \%$ lower. It suggested that farmers who are not constrained by informal credit are more likely to be confident on their health. The possible reason is that farmers who are not subject to informal credit can increase income and consumption capacity by obtaining informal credit and reduce their economic vulnerability. They can easily seek medical treatment in time when they are sick, and they don't have too much financial pressure to affect their mental health. Therefore, farmers who are not subject to informal credit constraints are in better health perception than those who are subject to credit constraints.

The above results are consistent with those revealed by the benchmark regression results, showing that informal credit constraints affect farmers' health. This showed that informal credit constraints can significantly decrease farmers' likelihood of judging their own health as good and increase their likelihood of judging their own health as bad. 
Table 3 - Regression results of the average treatment effect of informal credit constraints on farmers' self-rated health $(N=25,268)$.

\begin{tabular}{lcc}
\hline & & Marginal Effect (Standard Deviation) \\
\hline ATET_Pr1: $\operatorname{Pr}($ self-rated health $=1)$ & $(1$ vs. 0$)$ & $0.0081^{* * *}(0.0019)$ \\
ATET_Pr2: $\operatorname{Pr}($ self-rated health $=2)$ & $(1$ vs. 0$)$ & $0.0395^{* * *}(0.0055)$ \\
ATET_Pr3: $\operatorname{Pr}($ self-rated health $=3)$ & $(1$ vs. 0$)$ & $0.1168^{* * *}(0.0104)$ \\
ATET_Pr4: $\operatorname{Pr}($ self-rated health $=4)$ & $(1$ vs. 0$)$ & $0.1243^{* * *}(0.0085)$ \\
ATET_Pr5: $\operatorname{Pr}($ self-rated health $=5)$ & $(1$ vs. 0$)$ & $-0.2887^{* * *}(0.0159)$ \\
\hline
\end{tabular}

Note: ${ }^{* * *},{ }^{* *}$, and ${ }^{*}$ respectively indicate $\mathrm{P}<0.01, \mathrm{P}<0.05$, and $\mathrm{P}<0.1$. ATET means average treatment effect.

\section{Robustness test \\ Replacement of explained variables}

Since the self-rated health has a certain level of subjectivity, to improve the stability of the research conclusions, we used the sampled farmers' sick days in 2013 to characterize their health status. Table 4 reports the Tobit regression results of the impact of informal credit constraints on farmers' sick days in 2013. Similar to table 2, only informal constraint variables are added in column 1 of table 4,with no other control variables added; informal credit constraint variables and provinces where the farmers are located are added in column 2 ; informal credit constraint variables, the individual characteristics of the farmers, and the provinces where the farmers are located are added in column 3 ; and informal credit constraint variables, the individual characteristics, family characteristics, and the provinces where the peasants are located are added in column 4.

The results of columns 1-4 show that informal credit constraints significantly positively impacted the number of sick days in 2013, which means farmers who suffered from informal credit constraints had more sick days than those who did not experience in 2013. Thus, informal credit constraints significantly negatively impacted farmers' health. The above results show that informal credit constraints have a significantly negative impact on farmers' health, which means that our conclusion of has strong robustness.

Sub-sample regression of the average treatment effect To test the heterogeneity impact of informal credit constraints on farmers' self-rated health, we conducted a sub-sample regression of the average treatment effect of informal credit constraints on farmers' self-rated health. We used male, female, Han, and non-Han as sub-samples for the regression, and the results are reported in table 5. Results showed that the data presented by each sub-sample are basically consistent with that of the sample as a whole, which means that informal credit constraints can significantly decrease farmers' likelihood of judging their own health as good and can increase

Table 4 - Tobit regression results of the impact of informal credit constraints on farmers' sick days in $2013(N=24,940)$.

\begin{tabular}{lcccc}
\hline Variable & $(1)$ & $(2)$ & $(3)$ & $(4)$ \\
\hline Informal credit constraints & $0.7681^{* * *}(0.1646)$ & $0.5724^{* * *}(0.1473)$ & $0.6029^{* * *}(0.1437)$ & $0.4714^{* * *}(0.1416)$ \\
Individual characteristics & No & No & Yes & Yes \\
Family characteristics & No & No & No & Yes \\
Province & No & Yes & Yes & Yes \\
\hline
\end{tabular}

Note: ${ }^{* * *},{ }^{* *}$, and ${ }^{*}$ respectively indicate $\mathrm{P}<0.01, \mathrm{P}<0.05$, and $\mathrm{P}<0.1$. The standard errors aggregated at the village level are in parentheses. 
their likelihood of judging their own health as bad. The robustness of the conclusions was again proven.

\section{Investigation of different age groups}

To investigate the heterogeneity of the effect of informal credit constraints on the selfrated health of farmers from different age groups, we performed a relevant effect regression of the average treatment. The results are reported in table 6 . Results showed that the regularity of each age group was basically consistent with that of the sample as a whole. Specifically, in all age groups, compared with farmers who had never suffered from informal credit constraints, farmers with informal credit constraints had a significantly lower probability of evaluating their own health as very good and a significantly higher probability of evaluating their own health as bad. The robustness of the conclusions was proven.

\section{CONCLUSION}

Based on the survey data related to the income distribution and living conditions of urban and rural residents collected by the China Economic Monitoring and Analysis Center in 2014, we investigated the mechanisms related to informal credit constraints on farmers' health, and then we conducted an empirical analysis of this impact. Results showed that, in general, informal credit constraints have a significantly negative impact on farmers' health. Compared with farmers without informal credit constraints, the probability of farmers suffering from informal credit constraints choosing to self-rate their health as very good was $6.64 \%$ lower. After controlling for endogenous problems, this proportion rose to $28.87 \%$. Correspondingly, compared with farmers without informal credit constraints, the probability of farmers suffering from informal credit constraints choosing to selfrate their health as very bad was $0.45 \%$ higher. After controlling for endogenous problems, this proportion rose to $0.81 \%$. The robustness test showed that the research conclusions here have strong robustness.

In terms of policy recommendations, the following three aspects should be considered: First, the factors, superficial to deep, affecting farmers' health should be identified. As stated earlier, health is the basic premise of individual sustainable development, providing important support for the sustainable development of human society. Health is an important right for their farmer survival and development. Maintaining a good health status can effectively prevent farmers from damaging their health and falling into poverty. Thus, maintaining a good living standard can lead to the creation of a sustainable development space and improve individual wellbeing. Therefore, studying the factors influencing farmers' health is important and then formulating corresponding intervention measures, which are a concern of policy makers. At present, many studies have revealed factors influencing health, such as diet and the working environment. However, those factors are the easiest to superficially identify. For example, informal credit constraints, which were the focus of this paper, have a certain level of concealment and are difficult to identify and detect. We highlighted that the research of such hidden factors has academic value and should be one of the directions for research regarding farmers' welfare in the future.

Table 5 - Average treatment effect of informal credit constraints on farmers' self-rated health by sub-sample regression.

\begin{tabular}{|c|c|c|c|c|c|}
\hline \multicolumn{2}{|c|}{------------------Level of self-rated health-------------- } & \multirow{2}{*}{$\begin{array}{c}\text { Male } \\
0.0056^{* * *} \\
(0.0021)\end{array}$} & \multirow{2}{*}{$\begin{array}{c}\text { Female } \\
0.0119^{* * *} \\
(0.0037)\end{array}$} & \multirow{2}{*}{$\begin{array}{l}\text { Han nationality } \\
\qquad \begin{array}{c}0.0107^{* * *} \\
(0.0024)\end{array}\end{array}$} & \multirow{2}{*}{$\begin{array}{c}\begin{array}{c}\text { Non-Han } \\
\text { nationality }\end{array} \\
0.0141 \\
(0.0110)\end{array}$} \\
\hline ATET_Pr1: Pr(self-rated health $=1)$ & $(1$ vs. 0$)$ & & & & \\
\hline ATET_Pr2: Pr(self-rated health $=2)$ & $(1$ vs. 0$)$ & $\begin{array}{l}0.0393^{* * *} \\
(0.0072)\end{array}$ & $\begin{array}{l}0.0408^{* * *} \\
(0.0088)\end{array}$ & $\begin{array}{l}0.0423^{* * *} \\
(0.0059)\end{array}$ & $\begin{array}{l}0.0532^{* *} \\
(0.0264)\end{array}$ \\
\hline ATET_Pr3: $\operatorname{Pr}($ self-rated health $=3)$ & $(1$ vs. 0$)$ & $\begin{array}{l}0.1146^{* * *} \\
(0.0135)\end{array}$ & $\begin{array}{l}0.1159^{* * *} \\
(0.0162)\end{array}$ & $\begin{array}{l}0.1141^{* * *} \\
(0.0107)\end{array}$ & $\begin{array}{l}0.1601^{* * *} \\
(0.0419)\end{array}$ \\
\hline ATET_Pr4: $\operatorname{Pr}($ self-rated health $=4)$ & $(1$ vs. 0$)$ & $\begin{array}{l}0.1617^{* * *} \\
(0.0118)\end{array}$ & $\begin{array}{l}0.0842^{* * *} \\
(0.0125)\end{array}$ & $\begin{array}{l}0.1126^{* * *} \\
(0.0088)\end{array}$ & $\begin{array}{l}0.1883^{* * *} \\
(0.0306)\end{array}$ \\
\hline ATET_Pr5: $\operatorname{Pr}($ self-rated health $=5)$ & $(1$ vs. 0$)$ & $\begin{array}{c}-0.3214^{* * *} \\
(0.0219)\end{array}$ & $\begin{array}{c}-0.2529^{* * *} \\
(0.0232)\end{array}$ & $\begin{array}{c}-0.2798^{* * *} \\
(0.0166)\end{array}$ & $\begin{array}{c}-0.4157^{* * *} \\
(0.0703)\end{array}$ \\
\hline
\end{tabular}

Note: ${ }^{* * *},{ }^{* *}$, and ${ }^{*}$ respectively indicate $\mathrm{P}<0.01, \mathrm{P}<0.05$, and $\mathrm{P}<0.1$. ATET means average treatment effect. 
Table 6 - Regression results of the average treatment effects of informal credit constraints on the self-rated health of farmers of different ages.

\begin{tabular}{|c|c|c|c|c|c|}
\hline \multicolumn{2}{|c|}{-------Level of self-rated health------ } & \multirow{2}{*}{$\begin{array}{c}18-30 \\
0.0030^{*} \\
(0.0018)\end{array}$} & \multirow{2}{*}{$\begin{array}{c}31-40 \\
0.0035 \\
(0.003)\end{array}$} & \multirow{2}{*}{$\begin{array}{c}41-50 \\
0.0089^{*} \\
(0.0048)\end{array}$} & \multirow{2}{*}{$\begin{array}{c}51-65 \\
0.0266^{* * *} \\
(0.0092)\end{array}$} \\
\hline $\begin{array}{l}\text { ATET_Pr1: Pr(self- } \\
\text { rated health }=1)\end{array}$ & $(1$ vs. 0$)$ & & & & \\
\hline $\begin{array}{l}\text { ATET_Pr2: Pr(self- } \\
\text { rated health }=2 \text { ) }\end{array}$ & (1 vs. 0$)$ & $\begin{array}{l}0.0087^{* *} \\
(0.0035)\end{array}$ & $\begin{array}{l}0.0277^{* *} \\
(0.0108)\end{array}$ & $\begin{array}{l}0.0647^{* * *} \\
(0.0160)\end{array}$ & $\begin{array}{l}0.0610^{* * *} \\
(0.0188)\end{array}$ \\
\hline $\begin{array}{l}\text { ATET_Pr3: Pr(self- } \\
\text { rated health }=3 \text { ) }\end{array}$ & $(1$ vs. 0$)$ & $\begin{array}{l}0.0713^{* * *} \\
(0.0141)\end{array}$ & $\begin{array}{l}0.0747^{* * *} \\
(0.0247)\end{array}$ & $\begin{array}{l}0.1605^{* * *} \\
(0.0225)\end{array}$ & $\begin{array}{l}0.1161^{* * *} \\
(0.0226)\end{array}$ \\
\hline $\begin{array}{l}\text { ATET_Pr4: } \operatorname{Pr}(\text { self- } \\
\text { rated health }=4)\end{array}$ & (1 vs. 0$)$ & $\begin{array}{l}0.3000^{* * *} \\
(0.0192)\end{array}$ & $\begin{array}{l}0.1161^{* * *} \\
(0.0204)\end{array}$ & $\begin{array}{l}0.1334^{* * *} \\
(0.0175)\end{array}$ & $\begin{array}{l}-0.0425^{*} \\
(0.0230)\end{array}$ \\
\hline $\begin{array}{l}\text { ATET_Pr5: Pr(self- } \\
\text { rated health }=5)\end{array}$ & $(1$ vs. 0$)$ & $\begin{array}{c}-0.3832^{* * *} \\
(0.0314)\end{array}$ & $\begin{array}{c}-0.2222^{* * *} \\
(0.0384)\end{array}$ & $\begin{array}{c}-0.3677^{* * *} \\
(0.0340)\end{array}$ & $\begin{array}{l}-0.1613^{* * *} \\
(0.0270)\end{array}$ \\
\hline
\end{tabular}

Note: ${ }^{* * *},{ }^{* *}$, and ${ }^{*}$ respectively indicate $\mathrm{P}<0.01, \mathrm{P}<0.05$, and $\mathrm{P}<0.1$. ATET means average treatment effect.

Second, we should establish and improve the informal credit system, protect informal credit rights, and achieve a virtuous circle of informal credit. According to the conclusions of this study, informal credit constraints negatively impacted farmers' health, which means that a lack of access to informal credit will significantly and negatively affect farmers' health. The reason why farmers have difficulty obtaining informal credit is as follows: farmers' social capital may be insufficient so fewer informal credit channels exist for them and the irregularity of informal credit cannot guarantee the creditor's rights, leading creditor to a risk averse attitude and the refusal to lend. Therefore, the key to solving the problem is to establish and improve the informal credit system, protect creditors' rights and interests to informal credit, and realize a virtuous circle of informal credit. A concrete method through which this could be achieved is the establishment of a whole control line process. First, the methods from formal financing institutions such as banks should be used as a reference, and common texts of informal credit contracts should be formulated for use by borrowers and lenders. Second, the village collective should provide a guarantee for borrowers and supervise the use of their borrowing funds. Third, the informal credit default behavior should be listed in the penalty clause of the village party's village rules as well as regulations to raise the borrower's default costs and lower the credit risk.

Third, a more essential approach is vigorously developing rural formal finance and gradually eliminated farmers' dependence on informal credit. As stated in our introduction, many studies have shown that farmers struggle to obtain loans through formal financial institutions, and formal credit constraints are strict, which leads to the development of informal credit behavior. This reflects the necessity of widely developing rural formal finance. The vigorous development of rural formal finance, the gradual reduction of farmers' dependence on informal credit, and the improvement of farmers' ability to access formal financial loans are the key factors in mitigating farmers' health problems caused by informal credit constraints.

This paper has some shortcomings. For example, due to the availability of data, cross-sectional data were used. Future studies should collect panel data to obtain more robust conclusions. Additionally, our measurement of farmers' health is not accurate enough due to data scarcity. Future research should use medical measurement methods to more scientifically measure the variables to improve the preciseness and conclusions of the research.

\section{ACKNOWLEDGEMENTS}

Annual Project of Sichuan Social Science (Project No. SC19C020), Soft Science Project of Science and Technology Department of Sichuan Province (Project No. 2019JDR0178), Sichuan University (Project No. 2020ziyan-gongguan3 \& skbsh2019-43), and Chengdu Philosophy and Social Sciences Planning Office (Project No. 2019L30).

\section{DECLARTION OF CONFLICT OF INTEREST}

The authors declare no conflict of interest. The founding sponsors had no role in the design of the study; in the 
collection, analyses, or interpretation of data; in the writing of the manuscript, and in the decision to publish the results.

\section{AUTHORS' CONTRIBUTIONS}

All authors have made contributions to the present research. Xinyue Dong was fully engaged in the paper writing and revision. Fan Yang was offered great insights in theoretical part and played the role of a supervisor.

\section{REFERENCES}

AKDEMIR, S. et al. Factors affecting the credit use of farmers Sample of subprovince of Tarsus, province of Mersin. Fresenius Environmental Bulletin, v.28, n.6, p.4729-4734, 2019. Available from: <https://www.researchgate.net/publication/335079085>. Accessed: Oct. 3, 2020.

ALDWIN, C. M.; REVENSON, T. A. Vulnerability to economic stress. American Journal of Community Psychology, v.14, n.2, p.161-175, 1986. Available from: <https://link.springer.com/ article/10.1007/BF00911819\#citeas $>$. Accessed: Sept. 10, 2020. doi: 10.1007/BF00911819.

AYYAGARI, M. et al. Formal versus informal finance: Evidence from China. The Review of Financial Studies, v.23, n.8, p.30483097, 2010. Available from: $<$ https://academic.oup.com/rfs/articleabstract $/ 23 / 8 / 3048 / 1588349$ ?redirectedFrom $=$ fulltext $>$. Accessed: Sept. 10, 2020. doi: 10.1093/rfs/hhq030.

BACCHETTA, P.; GERLACH. G. Consumption and credit constraints: International evidence. Journal of Monetary Economics, v.40, n.2, p.207-238, 1997. Available from: $<$ https://www.sciencedirect.com/science/article/abs/pii/ S0304393297000421>. Accessed: Sept. 10, 2020. doi: 10.1016/ S0304-3932(97)00042-1.

BLEAKLEY, H. Health, human capital, and development. Annual Review of Economics, v.2, n.1, p.283-310, 2010. Available from: <https://www.annualreviews.org/doi/abs/10.1146/annurev. economics.102308.124436>. Accessed: Sept. 10, 2020. doi: 10.1146/annurev.economics.102308.124436.

CAI, J. et al. Determinants of and socio-economic disparities in self-rated health in China. International Journal for Equity in Health, v.16, n.1, p.7, 2017. Available from: <https://link.springer. com/article/10.1186/s12939-016-0496-4\#citeas>. Accessed: Sept. 10, 2020. doi: 10.1186/s12939-016-0496-4.

CGN (Chinese Government Network). 2016. Available from: $<$ http://www.gov.cn/xinwen/2016-08/20/content_5101024.htm>. Accessed: Sept. 10, 2020.

CHAUDHURI, S.; GUPTA, M. R. Delayed formal credit, bribing and the informal credit market in agriculture: A theoretical analysis. Journal of Development Economics, v.51, n.2, p.433-449, 1996. Available from: <https:/www.sciencedirect.com/science/article/ abs/pii/S0304387896004075?via\%3Dihub>. Accessed: Sept. 10 2020. doi: 10.1016/S0304-3878(96)00407-5.

CLAUSSEN, B. Socioeconomic status and health. International Encyclopedia of the Social \& Behavioral Sciences (Second Edition), p.931-936, 2015. Available from: <https://www.sciencedirect.com/ science/article/pii/B9780080970868140437>. Accessed: Sept. 10 2020. doi: 10.1016/B978-0-08-097086-8.14043-7.
COHEN, S. et al. Social Relationships and Health. In: Social Support Measurement and Intervention: A Guide for Health and Social Scientists (edited by COHEN, S. et al.). Oxford University Press, 2000. doi: 10.1093/med:psych/9780195126709.003.000.

COLEMAN, J. S. Social capital in the creation of human capital. American Journal of Sociology, v.94, p.95-120, 1988. Available from: <https://www.journals.uchicago.edu/ doi/10.1086/228943\#pane-pcw-related $>$. Accessed: Sept. 10, 2020. doi: $10.1086 / 228943$.

COLEMAN, J. S. Social capital in the creation of human capital. Knowledge and Social Capital, p.17-41, 2000. Available from: $<$ https://www.sciencedirect.com/science/article/pii/B9780750 672221500052?via\%3Dihub>. Accessed: Sept. 10, 2020. doi: 10.1016/B978-0-7506-7222-1.50005-2.

CROPPENSTEDT, A.; MULLER, C. The impact of farmers' health and nutritional status on their productivity and efficiency: Evidence from Ethiopia. Economic Development and Cultural Change, v.48, n.3, p.475-502, 2000. Available from: $<$ https://www.journals. uchicago.edu/doi/abs/10.1086/452607>. Accessed: Sept. 10, 2020

CULLEN M; WHITEFORD H. The interrelations of social capital with health and mental health. Commonwealth of Australia: National Mental Health Strategy, Discussion Paper, 2001. Available from: <Erro! A referência de hiperlink não é válida.> Accessed: Sept. 10, 2020

DAYKIN, A. R.; MOFFATT, P. G. Analyzing ordered responses: A review of the ordered probit model. Understanding Statistics, v.1, n.3, p.157-166, 2002. Available from: $<$ https://www.tandfonline. com/doi/abs/10.1207/S15328031US0103 02>. Accessed: Sept. 10, 2020. doi: 10.1207/S15328031US0103_02.

ETTNER, S. L. New evidence on the relationship between income and health. Journal of Health Economics, v.15, n.1, p.67-85, 1996. Available from: <https://www.sciencedirect.com/science/ article/abs/pii/0167629695000321>. Accessed: Sept. 10, 2020. doi: https://doi.org/10.1016/0167-6296(95)00032-1.

FINK, G.; MASIYE, F. Health and agricultural productivity: Evidence from Zambia. Journal of Health Economics, v.42, p.151-164, 2015. Available from: $<$ https://www.sciencedirect.com/ science/article/abs/pii/S0167629615000521>. Accessed: Sept. 10, 2020. doi: 10.1016/j.jhealeco.2015.04.004.

HE, G. et al. Rethinking the credit demand and availability of farm household. Issues in Agricultural Economy, n.2, p.38-49, 2018. (in Chinese).

HE, R. W. et al. Research progress and tendency of sustainable livelihoods for peasant household in China. Progress in Geography, v.32, n.4, p.657-670, 2013. (in Chinese).

HOFF, K.; STIGLITZ, J. E. Introduction: Imperfect information and rural credit markets - Puzzles and policy perspectives. The World Bank Economic Review, v.4, n.3, p.235-250, 1990. Available from: <https:// academic.oup.com/wber/article-abstract/4/3/235/1673294?redirectedFro $\mathrm{m}=$ fulltext $>$. Accessed: Sept. 10, 2020. doi: 10.1093/wber/4.3.235.

IDLER, E. L.; BENYAMINI, Y. Self-rated health and mortality: A review of twenty-seven community studies. Journal of Health and Social Behavior, v.38, n.1, p.21-37, 1997. Available from: $<$ https://www.jstor.org/stable/2955359>. Accessed: Sept. 10, 2020. doi: $10.2307 / 2955359$. 
JIA, X. P. et al. Credit rationing of rural households in China. Agricultural Finance Review, v.70, n.1, p.37-54, 2010. Available from: $<$ https://www.emerald.com/insight/content/ doi/10.1108/00021461011042620/full/html>. Accessed: Sept. 10, 2020. doi: $10.1108 / 00021461011042620$.

KAWACHI, I. Social capital and community effects on population and individual health. Annals of the New York Academy of Sciences, n.896, p.120-130, 1999. Available from: <https:// pubmed.ncbi.nlm.nih.gov/10681893/>. Accessed: Sept. 10, 2020. doi: 10.1111/j.1749-6632.1999.tb08110.x.

KENNEDY, B. P. et al. Income distribution, socioeconomic status, and self-rated health in the United States: Multilevel analysis. British Medical Journal, v.317, n.7163, p.917-921, 1998. Available from: <https://www.jstor.org/stable/25180555> Accessed: Sept. 10, 2020. doi: 10.2307/25180555.

KESSLER, R. C.; CLEARY, P. D. Social class and psychological distress. American Sociological Review, v.45, n.3, p.463-478, 1980. Available from: <https://www.jstor.org/stable/2095178>. Accessed: Sept. 10, 2020. doi: 10.2307/2095178.

KHOI, P. D. et al. Formal and informal rural credit in the Mekong River Delta of Vietnam: Interaction and accessibility. Journal of Asian Economics, v.26, P.1-13, 2013. Available from: $\quad<$ https://www.sciencedirect.com/science/article/abs/pii/ S1049007813000183>. Accessed: Sept. 10, 2020. doi: 10.1016/j. asieco.2013.02.003.

KOCHAR, A. An empirical investigation of rationing constraints in rural credit markets in India. Journal of Development Economics, v.53, n.2, p.339-371, 1997. Available from: <https://www. sciencedirect.com/science/article/abs/pii/S0304387897000205>. Accessed: Sept. 10, 2020. doi: 10.1016/S0304-3878(97)00020-5.

KUMAR, C. S. et al. The impact of credit constraints on farm households: Survey results from India and China. Applied Economic Perspectives and Policy, v.35, n.3, p.508-527, 2013. Available from: <https://academic.oup.com/aepp/article-abstract/3 5/3/508/8112?redirectedFrom=fulltext $>$. Accessed: Sept. 10, 2020. doi: $10.1093 /$ aepp/ppt002.

LI, C.; SUN, T. Channel credit constraints, informal finance and farmers' welfare level. Reform, n.10, p.90-101, 2018. (in Chinese).

LIU, L. S. The impact of health on farmers' labor participation. Chinese Rural Economy, n.8, p.25-33, 2008. (in Chinese).

MA, J. et al. Inequality in Beijing: A spatial multilevel analysis of perceived environmental hazard and self-rated health. Annals of the Association of American Geographers, v.107, n.1, p.109129, 2017. Available from: $<$ https://www.tandfonline.com/doi/full/ 10.1080/24694452.2016.1224636>. Accessed: Sept. 10, 2020. doi: $10.1080 / 24694452.2016 .1224636$.

MARMOT, M. et al. Social inequalities in health: Next questions and converging evidence. Social Science \& Medicine, v.44, n.6, p.901-910, 1997. Available from: <https://www.sciencedirect.com science/article/abs/pii/S0277953696001943>. Accessed: Sept. 10, 2020. doi: 10.1016/S0277-9536(96)00194-3.

MILES, J. Tolerance and variance inflation factor. In: Encyclopedia of Statistics in Behavioral Science; Everitt, B. S., Howell, D. C., Ed.; John Wiley \& Sons: Ltd, Chichester. p.20552056, 2005. Available from: <https://onlinelibrary.wiley.com/doi/ pdf/10.1002/0470013192.bsa683>. Accessed: Sept. 10, 2020. doi: 10.1002/0470013192.bsa683.

MILLER, D. L. et al. Social capital and health in Indonesia. World Development, v.34, n.6, p.1084-1098, 2006. Available from: $\quad<$ https://www.sciencedirect.com/science/article/abs/pii/ S0305750X06000465>. Accessed: Sept. 10, 2020. doi: 10.1016/j. worlddev.2005.11.006.

NBSC (the National Bureau of Statistics of China). 2010. Available from: <http://www.stats.gov.cn/tjsj/pcsj/rkpc/6rp/indexch.htm>. Accessed: Sept. 10, 2020.

OGUNDARI, K.; AWOKUSE, T. Human capital contribution to economic growth in Sub-Saharan Africa: Does health status matter more than education? Economic Analysis and Policy, v.58, p.131-140, 2018. Available from: $<$ https://www.sciencedirect.com/ science/article/abs/pii/S0313592616302041>. Accessed: Sept. 10, 2020. doi: 10.1016/j.eap.2018.02.001.

PARK, H. et al. Health risk factors among Iowa farmers. The Journal of Rural Health, v.18, n.2, p.286-293, 2002. Available from: <https://onlinelibrary.wiley.com/doi/ abs/10.1111/j.1748-0361.2002.tb00888.x>. Accessed: Sept. 10, 2020. doi: 10.1111/j.1748-0361.2002.tb00888.x.

PDO (People's Daily Online). 2017. Available from: <http://cpc. people.com.cn/19th/n1/2017/1023/c414305-29602172.html>. Accessed: Sept. 10, 2020.

PENNINGTON, A. et al. The health impacts of women's low control in their living environment: A theory-based systematic review of observational studies in societies with profound gender discrimination. Health \& Place, v.51, p.1-10, 2018. Available from: <https://www.repository.cam.ac.uk/handle/1810/277115>. Accessed: Sept. 10, 2020. doi: 10.1016/j.healthplace.2018.02.001.

PETRICK, M. A microeconometric analysis of credit rationing in the polish farm sector. European Review of Agriculture Economics, v.31, n.1, p.77-101, 2004. Available from: <https:// www.onacademic.com/detail/journal 1000036607924910 490a. html $>$. Accessed: Sept. 10, 2020. doi: 10.1093/erae/31.1.77.

ERIC, I. M. D. Survival in old age: Physical, psychological and social correlates of longevity. Journal of the American Geriatrics Society, v.18, n.4, p.273-285, 1970. Available from: <https:/ onlinelibrary.wiley.com/doi/full/10.1111/j.1532-5415.1970. tb03180.x>. Accessed: Sept. 10, 2020. doi: 10.1111/j.15325415.1970.tb03180.x.

PORTERFIELD, S. L. Economic vulnerability among rural singlemother families. American Journal of Agricultural Economics, v.83, n.5, p.1302-1311, 2001. Available from: $<$ https://onlinelibrary. wiley.com/doi/abs/10.1111/0002-9092.00282>. Accessed: Sept. 10, 2020. doi: 10.1111/0002-9092.00282.

QIU, L.Y.; HU, X. P. Formal credit constraints and rural household's consumption structure: Empirical evidence from 4141 farmers in China. Journal of Agrotechnical Economics, n.8, p.16-25, 2018. (in Chinese).

SCHULTZ, T. W. Investment in human capital. The American Economic Review, v.51, p.1-17, 1961.

SELVAMANI, Y. et al. Association of sleep problems and sleep duration with self-rated health and grip strength among older adults 
in India and China: Results from the study on global aging and adult health (SAGE). Journal of Public Health, v.26, p.697-707, 2018. Available from: <https://link.springer.com/article/10.1007/ s10389-018-0906-8\#citeas>. Accessed: Sept. 10, 2020. doi: 10.1007/s10389-018-0906-8.

SEN, A. K. Development as Freedom. Oxford, Oxford University Press, 1999.

SIAMWALLA, A. et al. The Thai rural credit system: Public subsidies, private information, and segmented markets. The World Bank Economic Review, v.4, n.3, p.271-295, 1990. Available from: $<$ http://citeseerx.ist.psu.edu/viewdoc/download?doi=10.1.1 999.3175\&rep=rep1\&type $=$ pdf $>$. Accessed: Sept. 10, 2020. doi: 10.1093/wber/4.3.271.

SIMON, M.; SHALLONE, C. K. The impact of farmers' health and nutritional status on agricultural technical efficiency: Evidence from Masvingo rural communities. Journal of Agriculture \& Sustainability, v.3, n.1, p.1-15, 2013. Available from: <https://infinitypress.info/index. php/jas/article/view/101>. Accessed: Sept. 10, 2020.

SOHU. 2018. Available from: <https://www.sohu. com/a/225480625_162422>. Accessed: Sept. 10, 2020.

TRAN, M. C. et al. Credit constraints and their impact on farm household welfare. International Journal of Social Economics, v.43, n.8, p.782-803, 2016. Available from: $<$ https://www.emerald. com/insight/content/doi/10.1108/IJSE-11-2014-0243/full/html>. Accessed: Sept. 10, 2020. doi: 10.1108/IJSE-11-2014-0243.

TURVEY, C. et al. Borrowing amongst friends: The economics of informal credit in rural China. China
Agricultural Economic Review, v.2, n.2, p.133-147, 2010. Available from: <https://www.emerald.com/insight/content/ doi $/ 10.1108 / 17561371011044261 /$ full/html $>$. Accessed: Sept. 10, 2020. doi: $10.1108 / 17561371011044261$.

WAGSTAFF, A.; DOORSLAER, E. V. Income inequality and health: What does the literature tell us? Annual Review of Public Health, v.21, n.1, p.543-567, 2000. Available from: $<$ https://www.annualreviews.org/doi/abs/10.1146/annurev. publhealth.21.1.543>. Accessed: Sept. 10, 2020. doi: 10.1146/ annurev.publhealth.21.1.543.

WILSON, J. J. et al. Association of objective sedentary behaviour and self-rated health in English older adults. BMC Research Notes, v.12, p.12, 2019. Available from: <https://link.springer. com/article/10.1186/s13104-019-4050-5\#citeas $>$. Accessed: Sept. 10, 2020. doi: https://doi.org/10.1186/s13104-019-4050-5.

YU, F. L. Health Capital Impact on Resource Allocation of Rural Residents' family. Yangzhou, Doctoral Dissertation of Yangzhou University, 2015. (in Chinese).

YUSUF, H. O. et al. The role of informal credit on agriculture: An assessment of small-scale maize farmers utilization of credit in Jema'a local government area of Kaduna State, Nigeria. American Journal of Experimental Agriculture, v.5, n.1, p.36-43, 2015. Available from: <https://www.sciencedomain. org/abstract/6056>. Accessed: Sept. 10, 2020. doi: 10.9734/ AJEA/2015/12099.

ZHOU, G. S. et al. The income disparity, the social capital and health: A case study based on China Family Panel Studies. Management World, n.7, p.12-21, 2014. (in Chinese). 